time trainees are looking for a senior registrar post. This may well give $\mathrm{S}$. Wales trainees a 'competitive edge' in the race for jobs.

(5) The main problem appears to be the extra work involved, and especially the need to write a dissertation around the time one is preparing for the Part 2 MRCPsych. This can be particularly difficult for those who require several attempts at the examination.

Overall, we feel that the benefits of the MSc greatly outweigh the problems. Not everyone completes the MSc, and in this sense it is not 'compulsory'. It provides a good opportunity to get involved in supervised research and to obtain a postgraduate degree.

IAN Jones and GaRY Suluvan

Gwent Community Health.

National Health Service Trust.

St. Cadoc's Hospital, Lodge Road,

Caerleon, Gwent NP6 $1 X Q$

\section{Poychiatric training in police surgeon work}

Sir: I would like to describe an experience of police surgeon casework and suggest that psychiatrists with an interest in Diversion from Custody might do some training with police surgeons.

I surveyed the cases seen over one year as a psychiatric registrar working on a one in six night time police surgeon rota in Ashington. Northumberland. This was supervised by a senior police surgeon and two consultant psychiatrists. Twenty-nine males and four females charged with offences ranging from drunken driving to murder were seen. Eighteen of these individuals had physical injuries and twenty-two were intoxicated with alcohol, drugs or other substance combinations. Two detained persons presented with DSM-III-R manic episodes and another two with adjustment disorders. The work generated by intoxication was substantial and our assessments appeared to make a marked difference on the rate of inappropriate Section 136 cases being taken to the local psychiatric hospital. A major benefit was acquiring an insight into the requirements of diversion from custody from the perspective of the police and forging working relationships with police officers. The police welcomed a psychiatrist as a police surgeon.

There are insufficient police surgeon recruits and the best way to train in the diversion from custody of mental disordered offenders is still being evaluated. There may be a case for trainee psychiatrists interested in becoming diversion from custody consultants joining the ranks of police surgeons. This should be at registrar or senior registrar level, with supervision from a consultant psychiatrist as well as incorporating police surgeon training.

STEPHEN D. MARTIN

St Luke's Hospital, Middlesbrough TS4 3AF

\section{Stravinsky, Hogarth and Bedlam}

Sir: I read the article on Stravinsky and the Rake's Progress by Paul Crichton (Psychiatric Bulletin, August 1995, 19, 196-498) with interest, and incredulity. The Hollywood-style psychobiography of the composer in his late fifties shows some of the pitfalls and the pointlessness of such activity. Crichton's account of the years leading up to the opera's composition is misleading. He states that “... by 1947 Stravinsky's career was totally becalmed... he had written a couple of untempestuous orchestral pieces... He was depressed by the lack of originality...". In fact, between his arrival in California in May 1940 and his encounter with the Hogarth print in May 1947 Stravinsky completed the Symphony in C (1940) and composed the following works: Tango (1940), Dances Concertantes (1942), Circus Polka (1942), Four Norwegian Moods (1942), Ode (1943), Babel (1944), Scherzo à la Russe (1944), Scènes de Ballet (1944), Sonata (1944), Elegy (1944), Symphony in Three Movements (1945), Ebony Concerto (1945) Concerto in $D$ (1946). Orpheus (1947) and most of the Mass (1948) (White, 1979). These works all received their premières during this period and the list contains some of the most important and enjoyable music of Stravinsky's later years.

There is no evidence from contemporary memoirs that Stravinsky was 'depressed' and Robert Craft's assassination of the composer's character is presented out of context. One might wonder whether Craft's analysis was objective since in the same chapter he admits that "... our nervous systems and temperaments were virtually the same"; and later, "Stravinsky's personality was overwhelming and dominating... and I had to seek refuge from it to preserve my identity" (Craft, 1992). As if by way of confirmation of Stravinsky's instability Crichton points out that he knew de Falla, Satie and Nijinsky - all of whom were rated as highly disturbed by Felix Post (1994). What relevance has this to Stravinsky's mental state in the 1940s?

Perhaps the final moral of the Rake's Progress (Auden \& Kalman, 1951) itself should serve as a warning:

"For idle hands,

And hearts and minds,

The Devil finds,

A work to do.

A work, dear Sir, fair Madam,

For you and you". 


\section{References}

Auden, W. H. \& KaLLMan, C. (1951) The Rake's Progress (libretto). London: Faber \& Faber.

CRAFT, R. (1992) Stravinsky: Glimpses of a Life. London: Lime Tree.

Crichton, P. (1995) Stravinsky. Hogarth and Bedlam. Psychiatric Bulletin, 19, 496-498.

Post, F. (1994) Creativity and psychopathology. A study of 291 world-famous men. British Journal of Psychiatry. 165. $22-34$.

WhITE. E. W. (1979) Stravinsky: The Composer and his Works, 2nd edn. London: Faber \& Faber.

MichaEl Philpot

Maudsley Hospital, Denmark Hill,

London SE5 8AF

Sir: Dr Philpot is right to describe my account of Stravinsky's musical output in the 1940s as 'misleading' in that I should have made it clearer that it was not so much the quantity as the quality of his work which disappointed many of his admirers: much of it was, by comparison with his earlier achievements, relatively lightweight and conventional.

That Robert Craft's attitude towards Stravinsky was ambivalent is hardly surprising. However, as Stravinsky's close collaborator and friend he remains, apart from Stravinsky himself, the crucial source of information about Stravinsky's life and works after 1948. Dr Philpot claims that there is no evidence from contemporary memoirs that Stravinsky was depressed, although in the very memoir quoted by Dr Philpot, Craft (1992) makes several references to the crisis in Stravinsky's career and to Stravinsky's distress about the lack of originality in his work in the late 1940s and early 1950s. It was for this reason, according to Craft, that he let himself be persuaded to study the serial composers, Schoenberg and Webern. This view has been endorsed by the Stravinsky expert, Walsh (1993), who is preparing a biography of the composer.

Dr Philpot wonders what de Falla, Satie and Nijinsky may have to do with Stravinsky's mental state at this time, although this is clearly explained in my article. Aware of the psychological vulnerability of these artistic colleagues, whom he had known personally, Stravinsky, himself notoriously hypochondriacal, may have been fascinated by the figure of the mad musician in the Bedlam scene of Hogarth's Rake's Progress because he feared that he might lose not only his creativity, but his sanity.

It is unfortunate for Dr Philpot that his eagerness to score some superficially smart points reveals an equally superficial acquaintance with the contents, both of my article and the relevant sources. Perhaps the final moral of his letter is that only well-informed criticism is convincing and that polemics are no substitute for perusal.

\section{References}

Craft, R. (1992) Stravinsky: Glimpses of a Life. London: Lime Tree.

WALSH. S. (1993) Igor Stravinsky. In The Viking Book of Opera (eds A. Holden, N. Kenyon \& S. Walsh). London: Penguin Books.

P. CRICHTON

Maudsley Hospital, Denmark Hill,

London SE5 8AF

\section{The dilemma of peychiatrists in training}

Sir: I was interested to read the letter from Dr de Vries et al (Psychiatric Bulletin, January 1996. 20,53 ) concerning the place of examinations in the training of entrants to psychiatry. It is not the first time that the view has been expressed that examinations are a hindrance rather than an asset in this procedure.

I believe that your correspondents do the College a dis-service in emphasising the place of the examinations for the MRCPsych and ignoring the very considerable attention that the College has given to stressing the importance of satisfactory clinical experience, of supervision in clinical work and a range of formal teaching activities. In this context the examinations mark the completion of a comprehensive and planned period of training. After all, most trainees who have undergone approved training have little difficulty in satisfying the examiners.

An important feature of the examinations for Membership of the College and the training which precedes them is that they are the same for all entrants to our profession no matter which branch of psychiatry they subsequently enter. Specialist training at senior registrar level (soon to be specialist registrar) does not involve further examinations but is along the lines described by your correspondents. I believe that this generic training common to all psychiatrists has been a major factor in the success of the training schemes overseen by the College and by the JCHPT. How else, but by an examination could future specialists be encouraged to study the subject more broadly in their early years.

I believe that there is some truth in your correspondents' assertion that the examinations for MRCPsych have done little to encourage the teaching of research or to foster it among trainees. Changes are planned in the MRCPsych examinations which will go some way to meeting this deficiency. Details of these changes will be announced in due course. Readers will see from the recently published Curriculum for the Examinations that research methodology is an area of knowledge required of candidates.

R. H. S. MindHAM

Chief Examiner, School of Medicine, University of Leeds, Leeds LS2 9LT 